\title{
Translating Fashion into Danish
}

\author{
By Marie Riegels Melchior, Lise Skov \& Fabian Faurholt Csaba
}

\begin{abstract}
With their association to enterprise and innovation, creative industries have emerged as a legitimate concern in national cultural and economical policy in many countries across the world. In Denmark, the fashion business, in particular, has been hailed as a model for successful (post)industrial transformation. In this paper, we explore the birth of Danish fashion from the ashes of the country's clothing manufacturing industry, suggesting that the very notion of Danish fashion is indicative of - and enabled by - a development towards a polycentric fashion system. The intriguing idea that fashion could emanate from Denmark and secure growth, jobs and exports even outside the fashion business has taken hold among policymakers, and compelled the government to embrace fashion as a national project. In investigating the emergence and rising stature of Danish fashion, particular at home, we first establish a theoretical frame for understanding the cultural economic policy and the motives, principles and strategies behind it. Then - drawing inspiration from Michel Callon's "sociology of translation” with its moments of translation: problematization, interessement, enrolment and mobilization - we identify the actors and analyze their strategic roles and interrelationship through various phases of the development of Danish fashion. Callon's actor network theory (ANT) is based on the principle of "generalized symmetry" - originally using a single repertoire to analyze both society and nature. We adapt this principle to study the realms of market, culture and politics within a common analytical framework. In our analysis, the state responds to industry transformation, interprets it and develops its own agenda. But it can hardly be said to develop policies for the industry. On the contrary, we suggest, fashion is mobilized to lend its luster to the nation, its institutions and politicians.
\end{abstract}

Keywords: Fashion, cultural nationalism, cultural industries policy, Denmark, translation 


\section{Introduction}

During the past decade or so, governments around the world have embraced the cultural or creative industries as policy objects (Hesmondhalgh \& Pratt 2005; Kong 2000; Pratt 2005). The main impetus for the development of government strategies and policy in this realm has been to mobilize culture to promote economic development. The conception of creative industries and its subsequent diffusion has been linked to both the rejection of forms of cultural policy grounded on subsidy of fine arts as well as a set of subtle moves to legitimize and retain them (Hesmondhalgh 2008; O'Connor 2007). But the term is increasingly identified with a turn towards enterprise and innovation, which establishes creative industries as a legitimate concern in national cultural and economical policy (Keane \& Zhang 2008; O'Connor 2007). Denmark is no exception from this global trend.

In this article we explore the way in which the fashion industry has been enrolled in the cultural industries policy in Denmark, to the point that it is seen as the prime example of the cultural and experience economy. We take our inspiration from actor network theory, and more specifically from what Michel Callon has called a "sociology of translation" (Callon 1986) in two ways: Firstly, we analyze the Danish fashion industry as a mobilization of resources and institutions which has resulted in a hybrid, but relatively stable network. In this respect, we see translation as a continuous process. Secondly, we adopt actor network theory's principle of generalized symmetry, in this case not so much between nature and society, as between different domains in society - culture, economy, and politics. Among these, the connection between the fashion industry and policy has been almost entirely overlooked. Yet, as we will argue it is extremely important, not only because it offers recognition of an emergent designer fashion industry sector, but also because it mobilizes new ways of representing the nation. The article is based on the assumption that the study of the general must be informed by the specific. The empirical material we present is very local down to the ethnographic detail of names and dates. Thus, we believe that the Danish cultural industries policy's focus on the fashion industry can inform a general understanding of creative and cultural industries policy.

Our analysis of the approximation of government and fashion industry goes through what we term - again, drawing on Callon - four moments of translation: problematization, interessement, enrolment and mobilization of allies (Callon 1986). The first moment, problematization, is represented by the industry's adjustment to deindustrialization and the emergence of a designer fashion industry sector. This liberated fashion's image-production capacity from a struggling manufacturing industry. The second moment, interessement, is represented by the government's gradual reinterpretation of the cultural sector. Out of this process the fashion industry emerged as the model innovative industry, worthy of support. 
The third moment, enrolment, represents the stabilization of networks that occurs when actors accept their mutual roles. This occurred through the establishment of the Danish Fashion Institute in 2005. However, this has not led to inertia, but rather to an ongoing mobilization in response to changing government initiatives. The fourth moment, mobilization of allies, is characterized by leading politicians attending fashion week, endorsing Danish fashion designers and professing their excitement about fashion. It signifies that the fashion industry has come to play an important role in what we term cosmopolitan nationalist discourse. Fashion lends its luster not only to individual politicians, but to the post-industrial nation. Preceded by a section in which we establish an analytical framework for the study of cultural industries policy, the four moments of translating fashion into Danish provide the structure of the present article.

Our argument is based on the observation that there is considerable slippage between fashion understood as cultural phenomenon and fashion understood as clothing-derived industry. In many ways this ambiguity is productive. In news stories, for example, it allows images of catwalk models to signify a whole textile and clothing sector, although designer fashion is only a small segment of what is a highly diverse industry. At the political level it allows the fashion industry to signify a postindustrial cosmopolitan "fashion nation," a representation which politicians and governments have found increasingly attractive.

The Danish fashion industry consists of approximately 620 companies registered by Statistics Denmark as “wholesalers of clothing” (Deloitte 2008). These companies employ more than ten thousand people. In 2009, the industry had an annual turnover of DKK 21.3 billion, ninety-two percent of which came from sales to the three largest export markets, Denmark's neighboring countries Germany, Sweden and Norway (DFT 2010: 2). Fashion is considered to be the fourth biggest exporter among manufacturing industries, based on export profits of Danish clothing, textiles and leather goods. ${ }^{1}$ The industry is dominated by three companies, Bestseller, ${ }^{2}$ BTX Group ${ }^{3}$ and IC Companies, ${ }^{4}$ which jointly account for approximately 75 percent of total export profits. The remainder is made up of small companies, typically privately owned and owner-managed, mostly with less than ten full-time employees. ${ }^{5}$ The persuasive ranking as the one of the largest exporting industries, albeit in a highly de-industrialized economy, is often invoked as evidence of the success of Danish fashion. However, these statistics are poorly tuned to measure the changes they are intended to prove. For example, they do not include employment within media, modeling, styling, event organization, research and analysis or lobbying, even though we might expect such jobs to be significant for a designer-driven industry. Moreover, we might question whether clothing exports represent an appropriate performance indicator for a creative and experience-based industry. It is only by looking behind the figures, discourses and network alliances that we can understand the mutual mobilizations of the nation for fashion, and fashion for the nation. ${ }^{6}$ 


\section{Cultural Industries Policy}

Culture industries policy must negotiate tensions between fields of culture and economy, or, perhaps, more accurately, the institutions which divide and define them. As Jean-Christophe Agnew stated:

Aestheticism and economism effectively cartelized the social world by dividing cultural exchange and market exchange into separate disciplinary jurisdictions. As a consequence, the juncture of these two aspects of life vanished from view, and the deep and unacceptable division within market culture reemerged as the deep but eminently acceptable division between the market and culture. (Agnew1986: 6-7)

To frame and analyze some of these tensions, we will first address the object and objectives of cultural policy and then turn to different modes and models for the government of culture and cultural industries.

In a historical analysis, Tony Bennett groups the objectives of cultural policy into three broad and overlapping categories: the symbolic, the social and the economic. The symbolic use of culture refers to state support to cultural activities representing the power and virtues of a nation, people or political system. Absolutist monarchies used culture as means to bolster the power of the king, whereas art and culture later came to represent an abstract form of sovereignty vested in a democratic citizenry. The social use of culture represents efforts to steer the conduct and ways of life of the population. Historically, governments have "acted upon the social” through prohibitions as well as cultural provisions (Bennett 2001: 3093). Thus, the development of cultural institutions in the $19^{\text {th }}$ century, such as public libraries, museums, art galleries and concert halls, were parts of a larger scheme to civilize and enlighten lower strata of the population. Today, both symbolic and social aspects of cultural policy mostly reflect democratic principles of equal cultural entitlements. But according to Bennett, social and civic aspects of cultural policies have recently been overshadowed by economic interests and concerns. He links the unprecedented significance of economic aspects of cultural policy to the demise of manufacturing sectors and the rise of cultural and media industry in the wake of globalization, revolutions in information technology, and changing relations of work and leisure.

Andy Pratt offers a more fine-grained and schematic framework for mapping cultural policymaking. He argues that notions of culture are constructed through a number of intersecting discourses providing particular means of mobilizing the notion and defining its object (Pratt 2005). Pratt, like Bennett, identifies three main approaches to cultural policy. They both have "economic" and a "social" categories, but Pratt calls his third category "ideological/political”, rather than "symbolic." Two of the three subcategories under "ideological/political", "humanist" and "aesthetic," seem to fit under Bennett's label of the social. The "humanist" stance emphasizes the uplifting and civilizing properties of certain forms of culture, linking "great art" to transcendent experiences and values. It is Pratt's "nationalist" subcategory of ideological/political discourse that comes closest to 
Bennett's notion of symbolic uses of culture. It concerns the way notions of cultural particularism and achievement function in the construction of national identity. In Pratt's analysis, economic discourses of culture revolve around the issue of whether culture should be a private or public good. Here Pratt posits four approaches; the first construes culture as a private good, traded as cultural commodities and analyzed by policy-makers according to their direct or indirect impact on the economy. In this neoliberal line of thinking, public investment in cultural activities is justified if returns, such as urban regeneration, export earnings or national identity, exceed administration costs. Conversely, culture can be seen as a public good when it makes sense to provide it collectively, that is, when cost structure allows a good to be consumed by many at no extra cost, as in the case with radio. The two remaining economic discourses on culture identified by Pratt are rational choice approaches and its variant model of merit goods. The former explains government support for arts and culture in terms public consent; the latter deals with government policy towards goods that merit support although the public does not necessarily demand or value them. The social dimension in Pratt deals mainly with the institutional texture of policy making. Unlike Bennett, Pratt does not question culture as an object of state policy, but regards it as an arm of welfare policy akin to health and education.

We now turn to mechanisms employed in governing the cultural realm. In their influential analysis of the "arm's length" principle in public support for the arts, Hillman-Chartrand and McCaughey addressed the limits of government and proposed a typology of four modes of support for the arts (Hillman-Chartrand \& McCaughey 1989). The “arm's length” principle is a central feature of pluralist democracies to prevent undue concentration of power and conflict of interest. The role of the state ranges from a hands-off donor-driven "facilitator" model to a hands-on "engineer" model. In the former, associated with the US, the arts are supported indirectly through tax deductions to private and corporate donors. The latter, in which the state owns the means of artistic production, is known mainly from totalitarian regimes. In between, we find the "patron" and "architect" models, which allow culture a degree of autonomy from both market and state. The patron model, associated especially with Great Britain, gives expert councils the authority to prioritize and channel public support, whereas the architect model involves a more active role for the state, but not state monopolization of the cultural sphere. Their analysis expresses concerns that the arm's length principle, best ensured in the patron model, is under threat.

In the absence of any other system that is clearly superior, is not the arm's length arts council the most effective guarantee that in a democratic country the arts will not be crushed under the tyranny of present-day commercial, moral or political concerns? (Hillman-Chartrand \& McCaughey 1989: 3)

Aiming to escape the state/market dualism, Pratt suggests a scheme with three basic forms of governance, adding to market anarchy and state organizational hierarchy, the notion of heterarchy or self-organization. Self-organization represents 
“a new balance point," but should not be identified with either "patron" or "architect" models. Instead, Pratt suggests that heterarchy is linked to new forms of coordination emerging in the wake of the transition from Fordism to Post-Fordism, and represents a rather unexplored territory within cultural policy.

In a more radical break with traditional models, Keane and Zhang criticize the arm's length principle, which they find too closely aligned to static and conservative conceptions of culture (Keane \& Zhang 2008). Instead, they adopt Potts and Cunninghams' four model scheme, which they see as a more dynamic understanding of cultural industry's role in the international knowledge economy. Potts and Cunningham's model includes the "welfare model", based on the assumption that support for cultural industry must be justified by non-market or cultural value and must be transferred from other areas of the economy. The second "normal" model insists that the cultural sector is an industry (leisure or entertainment) as any other and should be treated as such. The two remaining models consider creative industries to play a positive role in the economy. The growth model assumes that they are of particular importance because they facilitate growth in other sectors. The final, emerging "creative economy" model goes even further in viewing creative industries as a crucial part of the whole economy's innovation system, a catalyst for growth and processes of change (Potts \& Cunningham 2008). Keane and Zhang advance the creative economy model, not only for economic reasons, but also for its role in promoting cultural vitality and diversity (Kean \& Zhang 2008).

Before we analyze Danish fashion in the light of the positions and objectives that emerge from the triangle of culture-market-government, we need to take a closer look at the industry's transition from a manufacturing sector to a designbased cultural industry.

\section{Problematization: From Clothing to Fashion Industry}

It is only quite recently, that the words "Danish" and "fashion" have come to form a natural compound, "Danish fashion” (“dansk mode”). Significantly, it was not until 2009 that the industry's trade association was renamed from The Federation of Danish Textile and Clothing (Dansk Textil og Beklædning) to Dansk Fashion and Textile (Dansk Mode og Textil). Until a decade ago, the industry shied away from using the term fashion, and designated itself as a clothing or apparel industry. For example, in Denmark in the 1950s, fashion was regarded as a foreign, elite and female phenomenon. Both consumers and industry were at the receiving end in a monocentric fashion system (Davis 1992: 201; Pouillard 2008). Fashion salons (modelsaloner) in leading Copenhagen department stores had licensing agreements with Paris haute couture houses, such as Dior, Chanel and Balmain, which enabled them to purchase sketches, patterns and the right to reproduce haute couture designs for a local clientele (Mortensen 1993). Ready-to-wear manufacturers also kept an eye on international fashion, although they did not see 
themselves as style arbiters. They did not, for example, present regular new collections of style, color and fabric. Neither did they produce a whole range of coordinated outfits, but concentrated primarily on single products, such as slacks, blouses, sweaters or women's jackets (Melchior 2008).

What happened in the 1960s was a profound transformation of the global fashion and clothing industry. Some describe it as "democratization" (Lipovetsky 1994; Breward 2003; English 2007), since fashion morphed from a privileged domain of artistic creators into an exciting, modern phenomenon that all manufacturers and consumers could participate in. As a consequence of this development, Danish manufacturers faced more imports, which made the domestic market increasingly competitive and forced them to seek export markets. This gave professionally trained fashion designers a central role during the 1960s, either as employees in the manufacturing industry supplying designs or as owner-managers of their own companies. Led by fashion designers such as Søs Drasbæk, Margit Brandt, Mugge Kølpin, Lise-Lotte Wiingaard, Lars Hillingsø, Sysser Ginsborg and Lennart Råholt, this was the first golden age of what since then has been termed "Danish fashion" (Melchior 2008). The designers of this era became known for a modern, yet functional style of fashionable clothing for young adults - women and men.

The following decades, however, brought bleak times to the Danish clothing industry. As result of the recession following the 1973 oil crisis, European Economic Community accession, and rise in imports of low cost apparel from Asia, Danish clothing manufacturers were struggling for survival. In what was to be a losing battle, some companies joined the unions' effort to preserve Danish jobs in the clothing industry, whereas others closed their factories and outsourced production to low-cost countries. By 1997, the industry's process of deindustrialization was almost complete. Significantly, the trade association changed its membership regulations to accept "whole-sellers of clothing," which as a membership group subsequently came to outnumber manufacturers during the 1990s.

After the vibrant 1960s, the following decades were short on visions for Danish fashion. The erosion of the manufacturing industry, the bedrock of the Fordist welfare state, was so overwhelming that, even in the mid-1990s, most newspaper headlines were pessimistic about the future. Nobody had predicted the emergence of a designer fashion industry sector, concentrating on design, branding and marketing. Instead of controlling their own manufacturing, these fashion designers relied entirely on global manufacturing and reaped the benefits of the increasing standard of low cost international suppliers, especially in China and India (Gibbon \& Thomsen 2002). In fact, outsourcing opened up a multitude of new design possibilities, including elaborate styles with sequins and embroidery, which would have been prohibitively expensive to produce in Europe (Skov 2003). Leading Danish fashion brands such as Munthe plus Simonsen, Bruuns Bazaar and Day Birger et Mikkelsen incorporated Indian embroidery and color schemes and for 
some years “ethnic bohemia” was seen as the Danish fashion identity (Melchior 2008). Both Bruuns Bazaar and Munthe plus Simonsen were able to get registered on the official show list of the French fashion trade organization during the biannual fashion week in Paris (in 1999 and 2000, respectively). For the emergent sector, this was an important recognition, signifying that Danish fashion had reached an international level. Further recognition came in 1998, when Danish fashion designers got their own trade fair, CPH Vision, which was held in a redeveloped industrial building in the old meat-packing district of Copenhagen. Until then, Copenhagen Fashion Week had for decades presented both women's, men's and children's wear under one roof in Bella Center, Copenhagen's leading exhibition centre. The new fashion fair was initiated by Jan Carlsen, former head of sales at the Bella Center. He became one of the mediators and institutional entrepreneurs who, while not formally belonging to the industry (for example counting in industry statistics), institutionalized a framework that was conducive to the development of the local fashion world and the international recognition of Danish fashion. Established as a Scandinavian fair for design-driven and street fashion companies, CPH Vision changed the face of the fashion week by presenting small independent companies as the industry's frontrunners. ${ }^{7}$

$\mathrm{CPH}$ Vision thus cemented the divide between price-driven companies, representing the bulk of the industry and exports, mostly located in provincial towns in the west of the Denmark - the mid-century center for textile and clothing manufacturing - and design-driven, mainly small companies, located in the capital, but capable of attracting media attention with catwalk shows and other hyped events. This split between "Copenhagen," the capital, and "Jutland," the provincial region, came to shape the industry's alliances and power struggles in the following decade. The first moment of translation had taken place: A fashion design industry sector had emerged as a postindustrial success story.

\section{Interessement: Cultural Industry Policy Discovers Fashion}

As long as the clothing industry has existed, it has been subject to government regulation aimed at improving industry performance or protecting labor. However, it is only in the past decade that the fashion industry has been the subject of cultural policy. It would seem as that policy makers stumbled across the fashion industry while looking to replace the old welfare model of cultural support with ways of linking cultural industries to innovation systems able to sustain postindustrial economies (cf. Keane \& Zhang 2008). In Denmark, the inscription of the fashion industry into the cultural industries policy has not taken place under the heading of creative industries as in the UK (and many other places), but as "the cultural and experience economy." Also, unlike the UK, the policy area has not been limited to 'designer fashion', but to the industry as a whole (Greater London Administration 2002). 
The Danish variety of cultural industries policy has been developed collaboratively by the Ministry of Business Affairs and the Ministry of Culture through a series of studies and ensuing initiatives. The first report was published in 2000 during the reign of the Social Democrat and Social Liberal Party coalition under the title, "Denmark's creative potential. A cultural and business political review" (Danmarks kreative potentiale. Kultur- og erhvervspolitisk redegørelse). Drawing heavily on American business pundits and management consultants, Joseph Pine and James Gilmore's 1999 book The Experience Economy, the report pointed to the need to link cultural and the commercial sectors in order to reap future economic potential in terms of new jobs related to creativity and design, export growth and business development (KUM \& OEM 2000: 5). Denmark’s potential for future growth was seen not in selling products alone, but in selling stories, experiences, and identities to the consumers. The report did not single out the fashion industry, but made reference to fashion designers as "market and commercial oriented entrepreneurs" (KUM \& OEM 2000: 71) and categorized the clothing industry among the cultural industries (KUM \& OEM 2000: 37). For the first time, fashion was represented as central to the policy goal of a profitable linkage between of design and business.

The Liberal-Conservative coalition government which came to power in 2001 continued and extended this policy discourse. In the 2003 collaborative report by the Ministry of Culture and the (merged and renamed) Ministry of Economic and Business Affairs, "Denmark in the cultural and experience economy - five new steps ahead” (Danmark i kultur- og oplevelsesøkonomien - 5 nye skridt på vejen), fashion was included as an independent area of interest, while the word "clothing" was omitted (KUM \& OEM 2003:8). The report highlighted the importance of creativity, design and innovation for sustaining competitiveness under conditions of globalization (KUM \& OEM 2003:14). Expressing the government's vision for exploiting synergies between culture and commerce, the report proposed initiatives, such as intensifying the international branding of Danish design and advancing professionalism of design-based companies, including fashion companies (KUM \& OEM 2003: 17). Although it is clear that the report zooms in on the design-driven segment of the fashion industry, it is never completed dissociated from the rest.

Later the same year, FORA, a newly established research and analysis unit in the Ministry of Economics and Business Affairs under the leadership of senior official Jørgen Rosted, adopted a new activist approach to industrial policy. Instead of seeking to distribute resources evenly in the whole field, as had previously been the case, specific industries - pharmaceutical and electronics in addition to fashion - were singled out as high-performing innovative sectors worthy of support. In the report, "Comparison of Danish and foreign framing conditions and innovation systems in the fashion industry” (Sammenligning af danske og udenlandske rammebetingelser og innovationssystemer inden for modebranchen) FO- 
RA endorsed the Danish fashion industry as a success story because even though the industry only employed half the workforce of fifteen years previous, it had doubled its turnover and export profits in the same period (FORA 2003: 17-18).

In presenting the fashion industry as an exemplary case for how to tackle globalization, the report singled out innovation, knowledge sharing/knowledge centers, and design education. Regarding innovation, the success of the Danish fashion industry was seen to be founded on the ability to control costs, termed "price innovation." Another success factor was user-driven innovation, a central theme of FORA's work in the coming years, defined as the ability to follow consumer demand instead of competitors or market reports. By defining these two types of innovation, the report aimed to include the whole fashion industry, rather than just the designers. But in the process, creativity and design were relegated to the background as innovation was reduced to either cost reduction or sophisticated market research (Skov 2008). With regards to knowledge sharing, the report cited the international example of the Flandern Fashion Institute (established 1998) and the development of the Antwerp fashion scene, in view of implementing a similar strategy. With regard to education, the report stated that the Danish fashion industry lacked a high level of systematic and research-based knowledge in its work with innovation. It would appear that the authors did not have much faith in the design schools, even though they were preparing for an academic upgrading to university status, which they obtained in 2010.

FORA went on to conduct an international benchmark study, published in 2005 under the title "User-driven innovation in Danish fashion - the fifth global fashion cluster" (Brugerdreven innovation i dansk mode - den 5. globale modeklynge). In fact, the headline "the fifth fashion cluster" was to become Denmark's first official fashion policy. The authors argued that Denmark should not compete with the leading world cities, Paris, London, Milan and New York, but aim to be recognized in fifth place, as a leading second-tier fashion city (FORA 2005). This goal was extremely ambitious, given the strength of the industry was in the mid-market segments - a fact also documented in the report. FORA both acknowledged and glossed over the regional divide between "Copenhagen” and "Jutland;" for example, it did not state whether it was only Copenhagen or the whole of Denmark which should aim to be the fifth fashion cluster. Instead, the argument went that in order to operate as a single cluster; the industry needed a network organization.

Although FORA's focus on innovation was not limited to cultural industries, its policy definition was formative for the government's large 2007 initiative for the cultural and experience economy, including four sector specific "experience zones," private and public partnerships based on a series of multi-stakeholder projects. The "fashion zone" was the first to be established. ${ }^{8}$ It is striking that two of the four experience zones, the fashion zone and the food culture zone, are devoted to old strongholds of Fordist Denmark - manufacturing and agriculture. The two remaining experience zones, devoted to music and computer games, represent 
more typical cultural industries. None of the cultural activities or institutions that had been favoured by traditional cultural policy were included in the new experience zones.

It should be clear that the government reports reviewed in this section have been more preoccupied with the ways in which the fashion industry could legitimize and advance its own policy agenda, than with identifying the fashion industry's own visions or policy expectations. Even so, industry actors have collaborated in the translation process, by adopting the language of policy documents, and addressing the concerns of the reports. As it was, the government's interest was to have extensive consequences for the fashion industry, nowhere with more enthusiasm than in the Danish Fashion Institute.

\section{Enrolment: The Danish Fashion Institute}

On November 1st 2005, the Danish Fashion Institute (the acronym DAFI quickly caught on) was founded by representatives of fashion industry and media. ${ }^{9}$ As the organization only mustered support from a limited number of companies, it was through the intervention of government officials that the initiative was realized, seven months after the publication of the FORA report which recommended the establishment of exactly such a network organization. Additional support came from the fur industry, which is big in Denmark. The alliance with the fur trade was brought about by special circumstances. After breaking away from the longstanding Nordic marketing collaboration and establishing a national brand "Kopenhagen Fur," the Danish fur industry devoted a substantial share of its global marketing budget to promoting Copenhagen as a fashion centre (Skov 2005). By contrast, the government alliance has proved more durable for DAFI.

Many countries have a "fashion council," for example, the British Fashion Council, founded in 1983, or the Swedish Fashion Council, founded 1979. ${ }^{10}$ As the name indicates these organizations have a representative function vis-à-vis national industries. By contrast, a "fashion institute" usually designates a technical training or design school, such as the Fashion Institute of Technology in New York or the Institut Français de la Mode in Paris. By comparison the Flandern Fashion Institute, established in 1998, was a new kind of institution. Although the Flemish textile and fashion industry were the first to promote Antwerp fashion designers, the institute is also committed to external partnerships in its promotion of the city of Antwerp, its fashion museum and design school. DAFI represented an even higher degree of detachment from both industry interests and educational responsibilities. ${ }^{11}$ In a phrase, used at the founding meeting, DAFI was established "for" and "by" the fashion industry. ${ }^{12}$ Its mission, directly based on the 2005 FORA report, is to coordinate industry activities and promote Danish fashion. The organization finances its staff and activities through a combination of membership fees (in 2005 there was 60 members of DAFI; by 2008 the number had increased 
to 109 members) and government funding. ${ }^{13}$ This made it possible to employ project manager, fashion TV anchor and magazine editor Eva Kruse as director (since 2007 on a full-time basis). By 2009, DAFI employed seven people.

The establishment of DAFI was a challenge to the trade association Dansk Fashion and Textile, which had the legitimacy of more than three hundred company-members, but had not been alert to the developments in cultural industries policy. DAFI's first activity was to position itself as the coordinating body of the biannual fashion week, promoting it under the name of Copenhagen Fashion Week, in spite of the fact that the trade association had used the name Copenhagen Fashion Days since 2004. While the trade association organized the major trade fair of the week, DAFI took it upon itself to coordinate the fashion show schedule, assign models to the different shows and publish a fashion week catalogue distributed to buyers and press and established a main show ground symbolically placed in the main entrance of the Copenhagen City Hall. DAFI also took charge of communicating the event to the public by broadcasting fashion shows on huge screens in public places, running an Internet-based fashion TV station during fashion week, and publishing a fashion week newspaper, Dansk Daily. The trade association eventually accepted this division of labor, although for a long time it held a grudge against DAFI's creaming off media attention. In the eyes of its members and the public, it is DAFI's work for Copenhagen Fashion Week which first and foremost has legitimized the organization (Melchior 2008).

The second task DAFI set itself was to define Danish fashion. It was already anticipated in the FORA reports that in order to stand out internationally, a Danish fashion cluster needed to compete on specific Danish competences, including cultural competences (FORA 2005: 60-62). DAFI's project was seen as a necessary step to establish a national branding platform, rather than a cultural debate or creative experiment, which would have involved the whole community of fashion professionals. Hence a report - Danish Fashion. History, Design, Identity - was commissioned from a group of design school researchers. ${ }^{14}$

The problem of defining a national fashion identity was by no means simple. The erosion of manufacturing industries has set design aesthetics afloat, to the point that ethnic styles from other places in the world had been seen as quintessential to Danish fashion. In many ways, the designer fashion industry sector was opposed to the egalitarian and practical values that had dominated the Danish welfare state until then. But the "Danish Fashion” study zoomed in on long-standing continuities in Danish fashion and design, just as it found that international perceptions were still colored by the 1950s boom of Danish and Scandinavian furniture design (Rasmussen 2006). The report pointed to accessibility as a common denominator for Danish fashion, both in terms of wearability and moderate prices, arguably, brought about by home market conditions, as Danish consumers' average spending on clothing historically has been less than neighboring countries (Melchior and Olsen-Rule 2006). Although this might seem as a difficult condi- 
tion for a nation that aims to be a major fashion centre, following the report, accessibility has been endorsed as a democratic, and even ethical, characteristic of Danish fashion. The fact that Danish fashion designer brands range at low prices, compared to their international counterparts, has sustained an export niche for affordable high fashion. Although the "Danish Fashion" report introduced more sophisticated ways of thinking about national identity in fashion, DAFI's attempt at developing and implementing a national branding strategy petered out. But, according to Director Eva Kruse, interviewed in 2008, it was still on the organization's agenda to define how Danish fashion can be branded in order to receive international recognition. ${ }^{15}$

The need for funding steered DAFI in a different direction. In the autumn of 2007, for instance, Danish Fashion Institute arranged a conference on corporate social responsibility in the fashion industry, sponsored by the Ministry of Economics and Business Affairs. This initiative was brought on by an acute crisis following the media exposure of dangerous working conditions and child labor among the suppliers of leading Danish and Swedish retailers. But DAFI's ethical turn, which made headlines for Copenhagen Fashion Week in 2008 and 2009, was also a preparation for the up-coming UN climate conference COP15, held in Copenhagen December 2009. It led to an alliance with Norwegian-initiated project NICE (Nordic Initiative Clean and Ethical) which operates in Nordic and Baltic countries, and the organization of a one day "Fashion Summit," during the UN conference, albeit outside the official program (Skov and Meier 2011). In addition, DAFI has been involved in a number of smaller projects, from supporting entrepreneurs to consolidating the place of fashion in the cultural economy.

By way of conclusion, DAFI can be said to be a highly responsive organization, with its radar directed at multiple opportunities for public funding. Occasionally, this external focus brings out grudges from its hinterland, especially from the part of the industry that identifies its purpose as selling clothes. But in the five years it has existed DAFI has also been acknowledged for attracting more media attention and government funding to the industry than it has had before. At the face of it, DAFI's activities might look like industry self-regulation of the type HillmanChartrand and McCaughey (1989) defined as the arm's length principle. In reality, the relationship is far more interventionist. Turning to Pratt's categories, Danish fashion perhaps represents an example of heterarchy, or self-organization, as a new balance point between state and market.

The enrollment of DAFI in the translation of Danish fashion shows how a network organization can be closely attuned to the new requirements of cultural industries policy. Firstly, the government has come to exercise a significant influence on the fashion industry, without market intervention, industry regulation or direct subsidy. Secondly, DAFI, with no clear mandate from its members, but a huge field of potential allies can move from one project to another without limitation in issues or number of projects, as long as external funding is available. Un- 
like a trade association, or indeed, the industry itself, DAFI has the potential for enormous expansion. Thirdly, as the government's policy agenda draws heavily on fashionable management concepts, such as "network organization," "experience economy," "user-driven innovation," and "corporate social responsibility" which are replaced at regular intervals, the willingness of DAFI to take on new projects advances government legitimacy and increases its chance of being seen as successful. It is ironical that the fashion industry has been the test case of the new cultural industries policy, because the fashion industry has traditionally supported market principles. Yet, under the aegis of liberalization of the cultural sector, an, until recently, liberalist industry is now a major recipient of government support. Perhaps the radiance of government recognition is to strong that the industry could only bask in its light. Or perhaps the industry is so fragmented that it is incapable of unified action. At least it has not taken an active role in pushing its own needs and visions onto the political agenda.

\section{Mobilization of Allies: Fashion Lends its Luster to Denmark}

As the fashion industry's post-industrial growth had been established as a national success, and designer fashion as its legitimate signifier, politicians also began to talk about Danish fashion in a new way, which we analyze in this section and see as a fourth translation moment. The politicians who have been spotted among the front row celebrities at fashion shows include changing Ministers of Culture and of Economics and Business Affairs, but there are several others.

In February 2009 even Prime Minister Anders Fogh Rasmussen ${ }^{16}$ of the liberalconservative ruling government attended the Copenhagen Fashion Week in a show of support for the industry under the financial crisis. After a meeting with managers of seven fashion companies, DAFI's director Eva Kruse took him on a guided tour of the fair which ended up at the catwalk show of prominent fashion brand Bruuns Bazaar. Joining the prime minister in the front row were two other cabinet ministers, the administrative leader of the Ministry of Culture, the Lord Mayor of Copenhagen and two other Copenhagen mayors. By his own admission unacquainted with the world of fashion, and unable to name the brand of his own suit, the Prime Minister described the show as "really exciting" and "a completely new experience.” As his political regime has promoted systematic mistrust of any kind of taste expertise, the fashion press took his statement as a friendly recognition of their field. Soon after, in an interview with Tyler Brûlé in Monocle, the trendy magazine on global affairs, business, culture and design, the prime minister singled out fashion as a significant national industry and image for Denmark. According to the prime minister, the fashion industry, along with other creative industries, is important for Denmark because it combines manufacturing and design (Brûlé 2009: 48). 
The prime minister's appearance at Copenhagen Fashion Week and in Monocle was not only evidence of the importance of fashion in the government's strategies and visions for Denmark. It also showed that fashion has emerged as a stage on which politicians can seek visibility for themselves. As Hesmondhalgh and Pratt have suggested, we need to consider government actions beyond those which formally declare themselves cultural industries policy (Hesmondhalgh \& Pratt 2005: 2). This involves the ways politicians and government officials can borrow a bit of the glamour of the fashion industry at the same time as they state their support for the cultural industries.

Copenhagen's Lord Mayor until 2009, Ritt Bjerregaard, a former European Commissioner, and leading member of the Social Democratic party, has also been a regular at fashion shows, just like some of her fellow Copenhagen mayors. Under her administration, the City Hall opened its doors for the fashion industry. With attendance of more than 65000 people Copenhagen Fashion Week is obviously an attractive event to give hospitality. The municipality valued Copenhagen Fashion Week as a showcase for Copenhagen as a design and fashion capital. But for Bjerregaard, bringing fashion week into the City Hall also represented a new style of government. From a closed-door bureaucratic base of operations, the City Hall turned into a place for fun and surprising events. For this reason it was important for Bjerregaard also to involve the general public in Copenhagen Fashion Week.

Just as Bjerregaard made fashion a vital element in the image of Copenhagen, she presented herself as a keen observer of fashion. Bjerregaard, in her late 60s and famous for her controlled appearance, made a point of wearing Danish fashion design on official occasions. Without losing sight of the ethical problems in the fashion industry - in particular she has expressed concern about underweight models and anorexia - she enthusiastically endorsed Copenhagen as a creative fashion city. In an interview of the fashion week newspaper Dansk Daily, Bjerregaard stated her view of the connection between local creativity and business:

I think Copenhageners are really inventive and have a uniquely fresh attitude when it comes to fashion. They mix the weirdest things. My eyes are always wide open with fascination when I see tube socks with miniskirts, for instance, and a lot of Copenhagen-based designers are able to convert these quirky trends into something that everyone can use. (Interview in Dansk Daily, February 2, 2009: 8).

On the basis of these two examples, we argue that fashion helps politicians tell new stories about the people of Denmark and Copenhagen. In contrast to the Fordist welfare state which had to contain all the class tensions of an industrial economy, in the post-Fordist era, the nation is imagined as a homogeneous community of sophisticated consumers-cum-producers. The conditions of such a highly globalised industry as fashion make it hard to isolate and evaluate national performance. But this ambiguity is exactly what makes fashion feed into a kind of cultural nationalism, which endorses the nation's symbolic command of the world, through statements in media, policy and industry such as the following: 
Denmark is "the fifth fashion cluster;" Copenhagen is "a European metropolis;" the Danes are "creative and enterprising;" Danish fashion designers have whole factories in India and Madagascar working "for" them, and their catwalk shows are "just like Paris and London."

It is telling that among all the politicians that stated their support for the Danish fashion industry, the nationalist party (Dansk Folkeparti) members have neither been seen nor heard. To be sure some fashion designers have voiced moderate criticism of Denmark's anti-foreign policies, but that would hardly have kept influential populist nationalist politicians from the catwalk if they had wished to be there. We therefore propose that there are two parallel nationalist discourses in Denmark. The one represented by the nationalist party takes a defensive stance, not only against immigration but any kind of adulteration of Danish culture, for example the adoption of English as an academic language. The second discourse is what Anders Fogh Rasmussen and Ritt Bjerregaard plug into when they talk about Denmark as a fashion nation. We term it cosmopolitan nationalism. It is a kind of nationalism because it does not promote cultural diversity; it is hard to find ethnic minorities in the Danish fashion world. Also, the boundary between Denmark and the rest of world is still imagined as a gigantic threshold - a single Danish fashion designer's catwalk show in London can be cause for national celebration.

For the nationalist party the nation is old, and must be protected and preserved against the threat of globalization. But according to cosmopolitan nationalism the nation is more like a renewable resource which can be reinvented in interaction with global society. If fashion is a system for regularized transience (Best 2006: 12), or a "catwalk economy," geared to the regular packaging and launching of novelties (Löfgren 2005), this fourth translation moment shows how it can provide a paradigm for the kind of flexibility governments wish to foster. What is more, as fashion operates by the logic of seduction and contamination, rather than that of accumulation (Lipovetsky 1994), it readily bestows its luster on anyone who comes into contact with it; a touch of fashion and the dusty old nation is as good as new.

\section{Conclusion: Nation on the Catwalk}

In this article we have analyzed four moments of translation which have shaped the Danish fashion industry into a post-industrial, politically interesting, projectoriented, nationally significant cultural industry. Each adjective refers to a moment of translation: the emergence of a designer fashion industry and growth of exports after the Danish factories had closed down; the government's selection of the fashion industry as an exemplary case for design-based innovation with longterm economic potential; the establishment of the Danish Fashion Institute as a free agent closely aligned with shifting government initiatives; and the inclusion 
of the fashion industry in cosmopolitan nationalist discourse, enabling the glamour of the catwalk to rub off on individual politicians and the nation as a whole.

If we are to define the Danish model of cultural industry policy in Keane and Zhang's terms, it seems to fall between a "growth model" and "creative economy model," although neither fully captures the rationale behind the policy (Keane \& Zhang 2008). Investment (in terms of funding, policy measures and attention) is justified not so much through either effects in facilitating growth in other sectors (except from perhaps branding Denmark) or igniting innovation, as establishing the fashion industry as a beacon showing other industries and nations the Danish path to prosperity in a globalized economy. As suggested, we have doubts about the extent to which economic objectives, rationales, calculations and analysis can explain the Danish government's “enlistment” of the fashion industry in the service of building a creative nation. The Danish government's growing interest in and efforts to shape the Danish fashion industry cannot be understood only, even or primarily, as an investment in future fashion industry jobs or export earnings. But as Bennett suggests, the categories whereby we might understand the objectives and rationales behind cultural policy overlap (Bennett 2001).

While government policy towards cultural industries are explained and justified by economic goals and discourses, our case suggests that the symbolic and social aspects are strongly at work beneath the economic rationales and rationalizations. The social aspect of the cultural industries policy lies in the description, and prescription, of the Danish population as creative and enterprising. The symbolic aspect of demonstrating political visions and power differs radically from previous times when cultural power was enshrined in solid buildings, monuments, and institutions. The new image of power is taken from the transient and flimsy world of fashion - the hyped launching of a new collection at the forefront of international trends, willfully forgetting that in a few months it can be found on the sales racks. In short, the Danish cultural industry policy is compelling because it translates fashion into Danish by putting the nation on the catwalk.

Marie Riegels Melchior is a part-time lecturer at the Department of Ethnology, University of Copenhagen, and Research Fellow at Designmuseum Danmark. In 2008 she did her PhD on Danish fashion 1950-2008. Currently she is engaged in a study of fashion in museums. E-mail: mrm@designmuseum.dk.

Lise Skov is associate professor of creative industries at Copenhagen Business School. A sociologist by training, she has done extensive research on fashion industries and designers in Japan, China and Europe. She is the editor of the West Europe volume in the Berg Encyclopedia of World Dress and Fashion (2010). Email: 1s.ikl@cbs.dk. 
Fabian Faurholt Csaba is associate professor at Copenhagen Business School's Department of Intercultural Communication and Management. He has a background in consumer culture theory and current research interests include cultural branding and children’s fashion. E-mail: fc.ikl@cbs.dk.

\section{Notes}

1 Based on 2003 figures, the fashion business (i.e. the export of clothing, textile and leather goods) with export profits of DKK 30 billion DKK made it the fourth biggest export manufacturing business, behind electronics and machine equipment (92.1 billion DKK), agricultural products (DKK 67.9 billion) and medicines (DKK 32.1 billion)(FORA 2005: 14).

2 Bestseller A/S (est. 1979) had in 2007 an annual turnover of 10.4 billion DKK and employed in Denmark 2.654 persons. The company represents ten different fashion brands for children, women's and men's wear and operated 1.740 own concept stores in 2007 (www.bestseller.com).

3 BTX Group A/S (est. 2005 when the capital fund EQT bought Brandtex A/S, est. 1935) had an annual turnover of DKK 3.2 billion and 1.593 employees in 2008. The company owns 19 different fashion brands aimed at both children, teenagers, women and men (www.btxgroup.dk).

4 IC Companys A/S (founded in 2001 through the merger of fashion companies InWear A/S (est. 1969) and Carli Gry International A/S (est. 1973). The company represents 11 different fashion brands for women's and men's wear. In 2006 the company's annual turnover was 3,023 billion DKK; it employed 2.200 people and operated 259 concept stores. The company is the only Danish fashion company publicly listed on Copenhagen Stock Exchange (www.iccompanys.dk).

5 According to a Deloitte report on the Danish fashion industry from 2008, 32 percent of the Danish fashion companies have 4-9 full-time employees (Deloitte 2008:17).

6 The first version of this article was first presented at the conference Government Encounter at Copenhagen Business School, May $4^{\text {th }}-5^{\text {th }}, 2009$. We are grateful for comments and suggestions made by the participants, and in particular by our discussant, Dr. Joanne Entwistle, London College of Fashion.

7 Interview with Jan Carlsen by Marie Riegels Melchior, October $10^{\text {th }}, 2005$.

8 The funding of the "Fashion zone" has reported to be 17 million DKK, partly from the Ministry of Economics and Business Affairs and partly by other government organization with an interest in promoting the Danish cultural and experience economy (Press release from the Ministry of Economics and Business Affairs, June 21 $1^{\text {st }}$, 2008).

9 The founding group at its inception in 2004 consisted of five persons: a fashion investor (Annelise Ryberg), a fashion journalist (Frederik Bjerregaard), a fashion designer and promoter (Rasmus Nordqvist), a fashion magazine editor (Ane Lynge) and a fashion photography agent (Thomas Hargreave). By 2005 it consisted only of three persons, and newcomer, Eva Kruse emerged as the leader.

10 In April 2010 a Copenhagen Fashion Council was formed to co-organize Copenhagen Fashion Week in an attempt to overcome fragmentation and rivalry in the business.

11 However, the board of directors represents a mixture of constituencies and interests. In the first board of directors Tom Steifel Kristensen was chairman (marketing director of Kopenhagen Fur, the cooperative of Danish breeders and fur processors). Other members of the board were: Henrik Theilbjørn (CEO of IC Companys A/S), Mads Nørgaard (owner and design manager of a Copenhagen-based fashion company), Karen Simonson (owner and head designer of a Copenhagen based fashion company), Anne Mette Zachariassen (Principal of the industry school Teko Center Danmark), Anders Knutsen (former CEO of Bang \& Oluf- 
sen, chairman of the board of directors at the food and ingredients company Danisco A/S and Copenhagen Business School) and Thomas Hargreave (owner of a photo agency and founding member of Danish Fashion Institute).

12 Field notes by Marie Riegels Melchior, November $1^{\text {st }}, 2005$.

13 The membership fee is approximately DKK 10000 per annum. In 2006, Danish Fashion Institute (DAFI) received support from the Ministry of Economic and Business Affairs (DKK 500000 for the planning of seminar activities), and the National Agency for Enterprise and Construction (DKK 1.5 million to establish and run a think tank for the Danish fashion industry). In 2007, DAFI received 100000 DKK from the Ministry of Economic and Business Affairs to host a seminar on corporate social responsibility in the fashion industry. In 2008, the Ministry of Economic and Business Affairs paid DAFI DKK 226000 to host a seminar on implementing user driven innovation in the fashion industry, and Copenhagen city council supported initiatives at Copenhagen Fashion Week over the next three years with DKK 1.8 million (Director Eva Kruse, Danish Fashion Institute in interview with Marie RiegelsMelchior, July $\left.16^{\text {th }}, 2008\right)$.

14 The team was led by Head of Research, Thomas Schiødt Rasmussen, (The Danish Design School), with PhD Candidate Marie Riegels Melchior (The Danish Design School and The Danish Museum of Art \& Design), and Research Assistant Nikolina Olsen-Rule (The Danish Design School) as researchers. The report was a flagship project for the newly established fashion research platform, MOKO, an abbreviation of Modekonsortiet (The Fashion Consortium).

15 Director Eva Kruse, Danish Fashion Institute, in interview with Marie Riegels Melchior, July $16^{\text {th }}, 2008$.

16 In spring 2009 Anders Fogh Rasmussen stepped down as Prime Minister to become Secretary General of NATO. He was replaced by Lars Løkke Rasmussen, who has not demonstrated any particular interest in fashion.

\section{References}

Agnew, Jean-Christophe (1986): Worlds Apart: The Market and the Theater in Anglo-American Thought, 1550-1750, Cambridge: Cambridge University Press.

Bennett, Tony (2001): “Cultural Policy”, J. S. Neil \& B. B. Paul (eds): International Encyclopedia of the Social \& Behavioral Sciences, Oxford: Pergamon, 3092-3097.

Best, Joel (2006): Flavour of the Month: Why Smart People Fall for Fads, Berkeley: University of California Press.

Breward, Christopher (2003): Fashion, Oxford: Oxford University Press.

Brûlé, Tyler (2009): “Q\&A. Premier League - Copenhagen”, MONOCLE, 3:21 (March 2009), 48.

Callon, Michel (1986): "Some Elements of a Sociology of Translation: Domestication of the Scallops and the Fishermen of St. Brieuc Bay”, John Law (ed.): Power, Action and Belief: A New Sociology of Knowledge?, London: Routledge, 196-233.

DFT (2010): Udvikling for den danske tekstil- og beklcedningsbranche 2005-2009, Herning: Dansk Fashion \& Textile.

Davis, Fred (1992): Fashion, Culture and Identity, Chicago: The University of Chicago Press.

Deloitte (2008): Analyse af beklcedningsbranchen - tendenser og udfordringer, Copenhagen: Deloitte.

English, Bonnie (2007): A Cultural History of Fashion in the Twentieth Century: From the Catwalk to the Sidewalk, Oxford: Berg.

FORA (2003): Sammenligning af danske og udenlandske rammebetingelser og innovationssystemer inden for modebranchen, Copenhagen: Økonomi- og Erhvervsministeriet.

FORA (2005): Brugerdreven innovation i dansk mode - den 5. globale modeklynge, Copenhagen: Økonomi- og Erhvervsministeriet. 
Gibbon, Peter \& Lotte Thomsen (2002): Scandinavian Clothing Retailers' Global Sourcing Patterns and Practices. CDR Working Paper Subseries, no. xxii, 2-14.

Greater London Administration (2002): Creativity London's Core Business, London: GLA Economics.

Hesmondhalgh, David (2008): “Cultural and Creative Industries”, Bennett, T. \& J. Frow (eds): The SAGE Handbook of Cultural Analysis, Los Angeles: SAGE, 552-569.

Hesmondhalgh, David \& Andy. C. Pratt (2005): “Cultural Industries and Cultural Policy”, International Journal of Cultural Policy, 11, 1-13.

Hillman-Chartrand, Harry \& Claire McCaughey (1989): “The Arm's Length Principle and the Arts: An International Perspective - Past, Present and Future”, M.C. Cumming \& J. M. D. Schuster (eds): Who's to Pay for the Arts? The International Search for Models of Support, New York: American Council for the Arts, 43-80.

Keane, Michael. A. \& Weihong Zhang (2008): “Cultural Creative Industries or Creative (Cultural) Industries?”, H.Hu (ed.): China's Cultural Industries Forum, Shanghai: Shanghai Peoples' Press, 1-16.

Kong, Lily (2000): “Culture, Economy, Policy: Trends and Developments”, Geoforum, 31, 385390.

KUM \& OEM (2000): Danmarks kreative potentiale. Kultur- og erhvervspolitisk redegørelse, Copenhagen: Kulturministeriet \& Erhvervsministeriet.

KUM \& OEM (2003): Danmark i kultur- og oplevelsesøkonomien - 5 nye skridt på vejen, Copenhagen: Kulturministeriet \& Økonomi- og Erhvervsministeriet.

Lipovetsky, Gilles (1994): The Empire of Fashion. Dressing Modern Democracy, Princeton: Princeton University Press.

Löfgren, Orvar (2005): “Catwalking and Coolhunting. The Production of Newness", Orvar Löfgren \& Robert Willim (eds): Magic, Culture and the New Economy, Oxford: Berg, 57-71.

Melchior, Marie Riegels (2008): Dansk på mode. En undersøgelse af design, identitet og historie $i$ dansk modeindustri, PhD dissertation, Copenhagen: The Danish Design School Press.

Melchior, Marie Riegels \& Nikolina Olsen-Rule (2006): "Konkluderende bemærkninger”, Thomas Schødt Rasmussen (ed.): Dansk mode. Historie, design, identitet, Copenhagen: MOKO, 91-93.

Mortensen, Erik (1993): ”Magasin a la mode”, Paul Hammerich (ed.): Magasin på tværs i 125 år, Copenhagen: Gyldendal, 165-184.

O'Connor, Justin (2007): The Cultural and Creative Industries. A Review of the Literature: A Report for Creative Partnerships, London: Creative Partnerships Arts Council England.

Potts, Jason \& Stuart Cunningham (2008): “Four Models of the Creative Industries”, International Journal of Cultural Policy, 14, 233-247.

Pouillard, Véronique (2008): "In the Shadow of Paris? French Haute Couture and Belgian Fashion between the Wars”, Regina Lee Blaszczyk (ed.): Producing Fashion. Commerce, Culture, and Consumers, Philadelphia: University of Pennsylvania Press, 62-81.

Pratt, Andy. C. (2005): “Cultural Industries and Public Policy: An Oxymoron?”, International Journal of Cultural Policy, 11, 31-44.

Rasmussen, Thomas Schødt (ed.) (2006): Dansk mode. Historie, design, identitet, Copenhagen: MOKO.

(2003): "Patterns of Culture in Global Fashion: Production, Representation and Agency", Scandinavian Journal of Design History, 13, 7-24.

- (2005): “The Return of the Fur Coat in a Commodity Chain Perspective”, Current Sociology, 51:1, 9-33.

(2008): "Politik, branche og forskning: Brugerinnovation og den danske modebranche”, Tore Kristensen et al. (eds): Når Oplevelser Møder Økonomi: kreative virksomheder, brancher og steder., Århus: Forlaget KLIM, 205-226.

Skov, Lise and Janne Meier (2011): “Configuring Sustainability at Fashion Week”, Brian Moeran \& Jesper Strandgaard Pedersen (eds): Negotiating Values in Creative Industries, Cambridge: Cambridge University Press. 